\title{
PAJAK DIGITAL: POTENSI DAN TANTANGAN
}

\author{
Dwi Marlina Wijayanti \\ UIN Sunan Kalijaga Yogyakarta \\ marlina.wijayanti@gmail.com
}

\begin{abstract}
This study aims to analyze the potential and challenges of taxation in the digital era and understanding the readiness of business actors conducting business activities through E-commerce (PMSE) to the new taxation rules. In addition, this study also provides an overview of taxation policies that are appropriate to the digital era. There are still many potential taxation that has not been touched. One of the biggest

potential is in digital companies. Tax regulations for digital companies are still under discussion by the government. But for business operators who carry out PMSE, there is a regulation which requires them to pay taxes. Observations indicate that the majority of business operators conducting PMSEs are not yet aware of the latest tax regulations. Literacy is needed so that more tax objects are aware on tax. Nevertheless, the results show that business operators are ready to be confirmed as taxpayers in accordance with applicable regulations. This is a big opportunity in the taxation sector.
\end{abstract}

Keywords: Digital Tax, E-commerce, Opportunities, Challenges

\begin{tabular}{l}
\hline PENDAHULUAN \\
\hline Era industri 4.0 membawa dampak pada \\
perpajakan. Muncul objek pajak baru yaitu \\
perusahaan digital. Perusahaan digital menjadi \\
objek yang dipertimbangkan karena mereka \\
menerima manfaat dari banyaknya masyarakat \\
yang menggunakan produk mereka.Beberapa \\
perusahaan digital besar yang banyak \\
digunakan di Indonesia adalah Google, \\
Amazon, Facebook, Twitter, Instagram, \\
Whatsupp dan lain sebagainya. Beberapa \\
perusahaan tersebut memiliki pengguna yang \\
sangat banyak. Data dari Kominfo \\
menunjukkan bahwa pengguna internet di \\
Indonesia mencapai 64,6\% atau 171 juta jiwa. \\
Dari 171 jiwa, sebanyak 83\% adalah \\
pengguna aplikasi Whatsupp. Berdasarkan \\
data tersebut, dapat diketahui bahwa \\
perusahaan Whatsupp menerima banyak \\
manfaat keuangan dari Indonesia. Tetapi, \\
mereka tidak dikenakan pajak akibat belum \\
adanya aturan yang mengatur mengenai \\
perpajakan perusahaan digital. Perlu
\end{tabular}

dilakukan penelitian yang menawarkan kebijakan pajak (Shevlin, 1999).

Kesulitan yang dirasakan terkait penerapan pajak di era digital tidak hanya dirasakan di Indonesia. Masalah ini menjadi topik yang banyakdiperbincangkan di seluruh dunia. Salah satunya adalah pada sidang G20 yang dilaksanakan di Jepang pada 2019. Sidang tersebutdihadiri oleh sejumlah negara yang tergabung dalam Organisation for Economic Co-operation and Development (OECD). OECD membahas mengani tantangan perpajakan di era digital (Hongler $\&$ Pistone, 2015). Berdasarkan penelitian yang dilakukan oleh OECD, diketahui bahwa resiko kehilangan pajak akibat Base Erosion and Profit Shifting (BEPS) pada negara berkembang mencapai 200 miliar USD per tahun. Untuk mengatasi masalah tersebut diperlukan aturan perpajakan baru yang ditujukan untuk perusahaan digital.Solusi untuk menemukan peraturan baru yang cocok dapat menggunakan peran akademi untuk melakukan riset dan menemukan ide. Tetapi 


\section{DWI MARLINA WIJAYANTI \\ Pajak Digital: Potensi Dan Tantangan}

belum banyak yang tertarik dalam membuat riset mengenai pajak (Herawati \& Bandi, 2017)

Ketiadaan aturan perpajakan pada perusahaan digital menghilangkan potensi yang seharusnya menjadi pendapatan negara. Selama ini aturan perpajakan mengatur bahwa objek pajak harus berbentuk sebagai Badan Usaha Tetap (BUT) yang memiliki kantor/perusahaan secara fisik. Padahal, perusahaan-perusahaan besar yang beroperasi di Indonesia sebagian besar adalah perusahaan asing yang kantornya terletak di luar negeri. Perusahaan seperti ini lepas dari kewajiban pajak karena aturan yang berlaku tidak meliputi perusahaan digital. Hal ini menjadi pembahasan penting untuk menerbitkan aturan perpajakan baru (Shevlin, 1999) dan tata cara pembayaran pajak untuk jenis perusahaan digital sesuai dengan era internet saat ini.

Pada era internet saat ini, hampir semua aktivitas dilakukan secara online. Kominfo menyebutkan bahwa internet banyak digunakan untuk menjual barang dan jasa. Hal ini ditandai dengan banyaknya jumlah $e$ commerce yang berkembang di Indonesia. Melakukan jual beli secara online memudahkan proses transaksi karena lebih efektif dan efisien. Melalui e-commerce, pelaku usaha dapat memasarkan produknya lebih luas dan pembeli juga dapat membeli produk tanpa datang ke lokasi jual (Cox \& Dale, 2001). Dampak perpajakan dari transaksi e-commerce memiliki peluang yang besar. Jumlah pelaku usaha yang melakukan jual beli di platform e-commerce sangat banyak. Hal ini menjadi peluang perpajakan baru bagi pemerintah. Oleh karena itu, pemerintah merespon perkembangan ini dengan mengeluarkan Peraturan Pemerintah (PP) Nomor 80 Tahun 2019.

Peraturan Pemerintah Nomor 80 Tahun 2019 tentang Perdagangan Melalui Sistem Elektronik menjelaskan bahwa pelapak di Toko online atau e-commerce diwajibkan memiliki izin usaha. Aturan ini juga berlaku untuk pelaku usaha yang berasal dari luar negeri yang secara aktif melakukan PMSE kepada konsumen yang ada di negara Indonesia. Mereka harus membuat kantor fisik sebagai perwakilannya untuk memenuhi kewajiban perpajakan yang diatur dalam pasal 8 PP tersebut.Rasionalisasinya adalah mereka yang memiliki usaha secara online maupun offline mendapatkan income dari penjualan mereka. Hal ini merupakan objek pajak yang potensial.

Pelaku usaha yang melakukan PMSE yang belum memiliki NPWP harus mendaftarkan diri dan bagi mereka yang memiliki omzet lebih dari 4,8 miliar per tahun maka wajib dikukuhkan sebagai Pengusaha Kena Pajak (PKP). Hal ini dijelaskan dalam pasal 3 ayat 9 Peraturan Menteri Keuangan (PMK) Nomor 210/PMK.010/2018 tentang Perlakuan Perpajakan atas Transaksi Perdagangan melalui Sistem Elektronik. PMK ini berlaku efektif per 1 April 2019 yang mengatur mengenai tata cara dan prosedur pemungutan pajak. PMK ini bertujuan untuk mendorong tingkat kepatuhan pajak dari pelaku bisnis online yang melakukan aktivitas bisnis melalui platform marketplace, online retail, classified ads, daily deals, atau media sosial.

Untuk mengetahui kesiapan pelaku usaha terhadap implementasi PP dan PMK tersebut maka peneliti melakukan survei kepada pelaku usaha yang melakukan PSME. Hal ini dilandasi dengan adanya hubungan yang positif antara kepatuhan wajib pajak pada pertumbuhan ekonomi (Caballe \& Panades, 1997). Sebagai warganegara yang baik, pelaku usaha wajib untuk mengikuti peraturan yang berlaku. Tetapi, tidak semua objek pajak mengetahui adanya peraturan dan mau membayar pajak atas usahanya. Oleh karena itu, peneliti melakukan survei untuk mengetahui persepsi wajib pajak terhadap peraturan perpajakan terbaru. Penelitian perpajakan masih belum banyak dilakukan oleh banyak peneliti (Herawati \& Bandi, 
2019). Oleh karena itu, peneliti memfasilitasi fenomena tersebut.

REVIEW LITERATUR DAN HIPOTESIS

\section{Pajak Digital dan E-commerce}

Pajak digital adalah pajak yang dikenakan kepada perusahaan-perusahaan yang produknya bergerak dalam bidang teknologi informasi. Perusahaan digital menjadi sumber pajak baru yang sedang dikejar oleh semua negara. Bentuk operasi dari produk perusahaan digital adalah menggunakan jaringan internet sebagai syarat penggunaan. Perusahaan digital besar yang memiliki banyak pengguna/konsumen diantaranya adalah Google, Amazon, Facebook, Twitter, Instagram, Whatsupp dan lain sebagainya. Produk dari perusahaan tersebut memiliki berbagai layanan yaitu layanan pesan, e-commerce, mesin pencari, hiburan, dan lain sebagainya.

Salah satu produk bisnis yang menjanjikan adalah $e$-commerce. E-commerce adalah aktivitas bisnis antara perusahaan dan konsumen yang melakukan pertukaran barang atau jasa melalui elektronik (Cox \& Dale, 2001). Pertukaran yang dilakukan dalam $e$ commerce berupa uang, barang, layanan, dan informasi (Consulting, 1999).Dale (1999) menyebutkan bahwa dalam menjalankan proses bisnis perlu pemperhatikan kualitas dari proses bisnis. Perusahaan digital memfasilitasi kualitas proses bisnis dengan membuat produk yang memudahkan konsumen dalam memnuhi kebutuhannya.

Sistem digital tidak asing lagi pada era 4.0. Hampir semua aspek kehidupan tidak lepas dari internet. Dalam melakukan aktivitas bisnis, e-commerce menjadi salah satu produk yang paling banyak digunakan. Hal ini karena e-commerce memberikan fitur yang memiliki aspek kemudahan dan kebermanfaatan (Barnes \& Vidgen, 2002). Konsumen menyukasi poses yang instan/cepat. $E$ commerce menjadi salah satu produk yang dapat mememuhi kebutuhan konsumen dengan cepat (Klopping \& McKinney 2004) dengan aktivitas online Shopping yang menjadi pilihan utama pada era saat ini.

\section{PP Nomor 80 Tahun 2019 dan PMK Nomor 210/PMK.010/2018}

Pertaruran Pemerintah (PP) Nomor 80

Tahun 2019 menjelaskan mengenai Perdagangan Melalui Sistem Elektronik (PMSE). PP ini menyebutkan bahwa PMSE merupakan bentuk perdagangan yang transaksinya dilakukan melalui perangkat dan prosedur elektronik. Hal ini merujuk pada perusahaan digital. Produk perusahaan digital umumnya berbentuk aplikasi dan dapat diakses menggunakan smartphone. Produk tersebut banyak berupa jasa digital. Jasa digital dalam PP ini dijelaskan sebagai jasa yang dikirim dan dapat dirasakan manfaatnya menggunakan jaringan internet dan tidak melibatkan banyak campur tangan manusia.

PMSE memanfaatkan sistem digital untuk melakukan iklan, penawaran, penerimaan, dan konfirmasi. Sistem perdagangan ini sangat bergantung dengan jaringan dan alat berupa smartphone atau komputer. Perusahaan harus memenuhi serangkaian persyaratan untuk melakukan PMSE, dimulai melakukan pendaftaran sesuai dengan peraturan perundang-undangan. PP ini juga mengatur apa saja yang wajib dilakukan sebagai sebuah perusahaan digital dan standar keamanan dalam melakukan proses bisnis.

PP ini juga menekankan bahwa pelapak di toko online atau e-commerce diwajibkan memiliki izin usaha. Hal ini juga berlaku untuk pelaku usaha yang berasal dari luar negeri yang secara aktif melakukan PMSE kepada konsumen yang ada di negara Indonesia. Perusahaan asing harus membuat kantor fisik di Indoensia sebagai perwakilannya untuk memenuhi kewajiban perpajakan yang diatur dalam pasal $8 \mathrm{PP}$ ini. Selain itu, Pelaku usaha harus mendaftarkan diri sebagai wajib pajak. Sesuai dengan PMK Nomor 210/PMK.010/2018 tentang Perlakuan 


\section{DWI MARLINA WIJAYANTI \\ Pajak Digital: Potensi Dan Tantangan}

Perpajakan atas Transaksi Perdagangan melalui Sistem Elektronik (E-commerce). Pelaku usaha yang memiliki omzet lebih dari 4,8 miliar per tahun wajib dikukuhkan sebagai Pengusaha Kena Pajak (PKP). Aturan ini dijelaskan dalam pasal 3 ayat 9 Peraturan Menteri Keuangan (PMK) Nomor 210/PMK.010/2018.

PMK Nomor 210/PMK.010/2018 menjelaskan tentang Perlakuan Perpajakan atas Transaksi Perdagangan melalui Sistem Elektronik. PMK ini menekan pada pembebanan pajak bagi pelaku usaha yang melakukan proses bisnis pada platform marketplace. Oleh karena itu, hal pertama yang ditekankan adalah kewajiban mendaftarkan diri sebagai wajib pajak bagi perusahaan yang telah mencapai penghasilan sejumlah tertentu. Selain itu. PMK ini menjelaskan mengenai perlakuan atas Pajak Pertambahan Nilai (PPN), Pajak Penjualan Atas Barang Mewah, dan Pajak Penghasilan Atas Transaksi Perdagangan Dalam Negeri Melalui Sistem Elektronik (E-commerce). Peraturan tersebut dibuat dengan tujuan untuk meningkatkan kepatuhan waajib pajak pada aturan perpajakan yang ada di Indonesia.

\section{Niat Membayar Pajak}

Setiap wajib pajak memiliki kewajiban untuk membayar pajak sesuai dengan ketentuan yang berlaku. Jenis pajak yang dibayarkan juga beragam sesuai dengan manfaat dari objek pajak yang dimanfaatkan atau dikonsumsi. Data dari Nota Keuangan dan RAPBN tahun 2019 menunjukkan bahwa jumlah wajib pajak pada tahun 2019 mencapai 42 juta wajib pajak. Jumlah ini cukup besar dan sangat potensial untuk meningkatkan penerimaan negara. Tetapi, fakta menunjukkan bahwa target penerimaan negara dari sektor pajak pada tahun 2019 tidak lebih dari $72 \%$. Hal ini menunjukkan bahwa tidak semua wajib pajak patuh pada aturan perpajakan.
Niat untuk melakukan sebuah aktivitas berbeda antara satu individu dengan individu yang lain (Ayers \& Kaplan, 2005), termasuk pada niat membayar pajak. Individu yang disebut sebagai wajib pajak memiliki kewajiban atas manfaat yang dirasakan atas sebuah objek pajak. Atas dasar prinsip keadilan maka sudah selayaknya untuk membayar pajak kepada negara. Niat membayar pajak berhubungan dengan kepatuhan pajak (Caballe \& Panades, 1997). Kepatuhan pajak menjadi masalah penting yang harus diselesaikan karena berhubungan dengan norma dan prinsip keadilan (Posner, 2000). Banyak faktor yang dpat mempengaruhi niat wajib pajak untuk membayar pajak. Salah satunya adalah kepatuhan pada aturan pemerintah (Turnovsky, 1997). Aturan pemerintah dapat berupa Undang-Undang dan peraturan lain yang memiliki kekuatan hukum yang mengikat.

Aturan pemerintah memiliki sifat memaksa. Meskipun demikian niat untuk membayar pajak sangat dipengaruhi oleh besaran pajak yang harus dibayarkan. (Caballe \& Panades, 1997). Tarif pajak berhubungan dengan penghindaran pajak (Boylan, 2010). Wajib pajak yang dalam proses mendapatkan penghasilan membutuhkan usaha yang cukup berat dan lama akan cenderung untuk sulit dalam menaati aturan perpajakan. Hal ini didukung oleh penelitian yang dilakukan oleh Boylan \&Sprinkle (2001). Oleh karena itu, peneliti melakukan survei pada pelaku usaha yang melakukan proses bisnis pada $e$ commerce untuk mengukur niat membayar pajak.

\section{METODE PENELITIAN}

Penelitian ini dilakukan dengan melakukan studi literatur untuk melihat peluang dan tantangan perpajakan digital di Indonesia. Studi literatur dilakukan dengan menganalisis kebijakan perpajakan yang berlaku di Indonesia dan perkembangan 


\section{JURNAL OPTIMUM, Volume 10, Nomor 1 Maret 2020}

perusahaan digital. Seperti dalam penelitian Isyrin (2019); Nurdianto (2019); Rosdiana et al. (2017); Richard (2018); dan beberapa artikel dalam laman berita. Literatur yang digunakan masih terbatas karena topik ini masih baru dalam dunia perpajakan. Selain itu, penelitian ini secara kualitatif melakukan analisis kesiapan pelaku usaha yang melakukan PMSE untuk mengimplementasikan PP Nomor 80 Tahun 2019 dan PMK Nomor 210/PMK.010/2018. Responden dalam penelitian ini adalah 42 pelaku usaha yang melakukan aktivitas penjualan secara online pada berbagai $e$ commerce. Responden diberikan pertanyaan tertutup pengenai peraturan perpajakan yang baru dan kesiapan mereka untuk aktif sebagai wajib pajak. Data dikumpulkan melalui survei secara online dan offline. Survei online dilakukan dengan menggunakan google form sedangkan survei secara offline dilakukan dengan paper based. Peneliti juga menyertakan pertanyaan terbuka pada responden untuk memberikan pandangan terkait PP no 80 tahun 2019 dan PMK Nomor 210/PMK.010/2018.

\section{HASIL PENELITIAN DAN PEMBAHASAN \\ Potensi Perpajakan di Era Digital}

Era Digital membawa perubahan pada berbagai aturan perpajakan. Istilah yang sering digunakan untuk sektor ekonomi digital adalah Over-The-Top (OTT). Potensi penerimanaan pajak dari sektor OTT sangat besar. Data dari Asosiasi Penyelenggara Jasa Internet Indonesia (APJII) menunjukkan bahwa kontribusi Indonesia terhadap OTT mecapai $\mathrm{Rp} 15$ triliun per tahun.Hal ini menunjukkan bahwa pendapatan negara dari sektor pajak dapat lebih besar dengan merambah objek pajak baru. Pajak sebagai sumber pendapatan utama negara harus dilaksanakan secara adil untuk semua elemen. Pada industri 4.0, pemerintah menemukan objek pajak baru yang potensial yaitu pajak dari aktivitas bisnis digital.
Solusi yang dapat dilakukan untuk mengenakan pajak pada perusahaan digital tanpa mengubah sistem yang telah ada adalah dengan menerapkan Pajak Pertambahan Nilai (PPN). PPN menjadi solusi untuk transaksi digital lintas negara. Rasionalnya, pajak tidak hanya dibebankan kepada perusahaan melainkan konsumen yang menerima manfaat juga dapat dibebankan pajak. Berbeda dengan $\mathrm{PPh}$, PPN menganut prinsip destinasi. Artinya, pajak dikenakan dimana barang atau jasa dikonsumsi. Hal ini dapat diterapkan untuk perusahaan-perusahaan digital yang tidak memiliki kantor perwakilan secara fisik di Indonesia tetapi Indonesia menjadi negara sumber penghasil pendapatan mereka.

Direktur Eksekutif Center For Indonesia Taxation Analysis (CITA), Yustinus Prastowo, menyebutkan bahwa mekanisme yang tepat untuk diterapkan adalahsupplier collection. Artinya, pemungutan PPN dilakukan oleh supplier asing yang memiliki omzet melebihi Rp 4,8 miliar. Mekanisme ini telah diterapkan di 29 negara yang tergabung dalam OECD dan juga diterapkan di beberapa negara di Uni Eropa, Rusia, India, dan Afrika Selatan. Meskipun demikian, untuk menerapkan kebijakan ini perlu melakukan revisi Undang-Undang PPN Pasal 3A ayat 3 yang isinya mengatur mengenai consumer collection sehingga Pasal 2 UU KUP yang mengatur tempat dan syarat pendaftaran menjadi tidak relevan. Gagasan ini didukung oleh Kepala Pusat Kebijakan Pendapatan Negara BKF, Rofyanto Kurniawan, menyebutkan bahwa pengimplementasian skema PPN untuk OTT memiliki kemungkinan untuk diterapkan di Indonesia.

Yustinus juga menyebutkan bahwa potensi pasar digital itu diperkirakan mencapai USD 130 miliar di 2020. Hal ini merupakan peluang besar pada sektor ekonomi digital. Saat ini banyak investor mulai berminat pada industri digital. Pemerintah sebagai pembuat kebijakan harus dengan cepat merespon perubahan di industri 4.0. Hal ini diperlukan sebagai bentuk 


\section{DWI MARLINA WIJAYANTI \\ Pajak Digital: Potensi Dan Tantangan}

keadilan bahwa negara harus memperoleh haknya karena perusahaan mendapatkan manfaat dari aktivitas bisnis di Indonesia.

\section{Tantangan Perpajakan di Era Digital}

Upaya yang dilakukan pemerintah untuk menghimpun pajak dari perusahaan digital adalah dengan mendesain dan merumuskan kebijakan baru yang sesuai. Pemerintah perlu mendefinisikan kembali BUT menjadi lebih luas. BUT yang selama ini harus berbentuk fisik harus diperluas denganmempertimbangkan kompleksitas struktur digital sebuah perusahaan. Banyak perusahaan digital yang berasal dari luar negeri dan beroperasi di dalam negeri tetapi tidak memiliki kantor fisik di Indonesia. Apabila mengacu pada definisi lama BUT maka perusahaan seperti ini tidak dapat dikenakan pajak. Oleh karena itu redefinisi diperlukan untuk menarik objek pajak baru.

Selain itu, pemerintah perlu memperhatikan signifikansi dari kehadiran sebuah perusahaan digital. Perusahaan digital dengan pengguna yang banyak telah banyak menerima manfaat keuangan dari beroperasinya di Indonesia. Perlu dilakukan peritungan kuantitatif dari manfaat tersebut. Sebagai upaya nyata yang dilakukan pemerintah adalah dengan merencanakan akan membuat Rancangan Undang-Undang (RUU) mengenai Ketentuan dan Fasilitas Perpajakan. Hal ini dilakukan untuk Penguatan Perekonomian yang dilakukan dengan membuat kebijakan-kebijakan sebagai upaya untuk meningkatkan aktivitas ekonomi dari sektor perpajakan.

Banyak negara yang masih sulit mengatur kebijakan perpajakan untuk perusahaan digital. Pengenaan pajak untuk sektor OTT tidak dapat menggunakan aturan dalam pajak penghasilan (PPh). Hal ini dikarenakan pengenaan pajak penghasilan lintas negara masih berpedoman pada keberadaan fisik perusahaan di Indonesia. Padahal, era sekarang menunjukkan bahwa praktik bisnis sudah berubah. Perusahaan asing tidak perlu mendirikan perusahaan secara fisik di Indonesia untuk dapat melakukan aktivitas bisnis. Oleh karena itu, pemerintah sedang melakukan pembahasan untuk mengatasi masalah tersebut.

HASIL ANALISIS DAN PEMBAHASAN

Responden dalam penelitian ini adalah 42 pelaku usaha yang melakukan aktivitas penjualan secara online pada berbagai $e$ commerce. Data dikumpulkan secara online dan offline. Responden mengisi secara langsung kuesioner yang berisi pertanyaan tertutup dan pertanyaan terbuka mengenai pengetahuan tentang PP Nomor 80 Tahun 2019 dan PMK Nomor 210/PMK.010/2018 serta kesiapan mereka sebagai wajib pajak baru untuk patuh pada aturan perpajakan. Berikut merupakan karakteristik demografi dari responden.

\section{Tabel 1.}

Karakteristik Demografi Responden

\begin{tabular}{|c|c|c|c|c|}
\hline Karakteristik & Keterangan & Jumlah & Total & Persentase \\
\hline \multirow[t]{2}{*}{ Gender } & Laki-laki & 18 & \multirow{2}{*}{42} & $42,86 \%$ \\
\hline & Perempuan & 24 & & $57,14 \%$ \\
\hline \multirow[t]{6}{*}{$\begin{array}{l}\text { Kategori } \\
\text { Usaha }\end{array}$} & $\begin{array}{l}\text { Handphone, } \\
\text { komputer, } \\
\text { dan aksesoris }\end{array}$ & 4 & \multirow{6}{*}{42} & $9,52 \%$ \\
\hline & Kecantikan & 11 & & $26,19 \%$ \\
\hline & Fashion & 16 & & $38,10 \%$ \\
\hline & Elektronik & 1 & & $2,38 \%$ \\
\hline & $\begin{array}{l}\text { Makanan dan } \\
\text { minuman }\end{array}$ & 7 & & $16,67 \%$ \\
\hline & $\begin{array}{l}\text { Perlengkapan } \\
\text { rumah }\end{array}$ & 3 & & $7,14 \%$ \\
\hline \multirow[t]{3}{*}{ Lama Usaha } & $<3$ tahun & 12 & \multirow[t]{3}{*}{42} & $28,57 \%$ \\
\hline & $3-5$ tahun & 28 & & $66,67 \%$ \\
\hline & $>5$ tahun & 2 & & $4,76 \%$ \\
\hline \multirow{2}{*}{$\begin{array}{l}\text { Kepemilikan } \\
\text { NPWP }\end{array}$} & $\mathrm{Ya}$ & 28 & \multirow[t]{2}{*}{42} & $66,67 \%$ \\
\hline & Tidak & 14 & & $33.33 \%$ \\
\hline
\end{tabular}

Tabel 1 menjelaskan bahwa sebagian besar responden memiliki usaha fashion. Usaha ini cukup menjanjikan pada era 4.0 saat ini karena konsumen mulai beralih untuk membeli secara online dibandingkan membeli langsung ke toko atau mall. Selain itu, berdasarkan pertanyaan terbuka yang 
diberikan kepada responden, e-commerce yang menjadi lapak bagi para responden diantaranya adalah Shopee, Tokopedia, Lazada, OLX, Bukalapak, dan Blibli.

Berdasarkan data yang dikumpulkan, diketahui bahwa sebagian besar pelaku usaha belum mengetahui adanya PP Nomor 80 Tahun 2019 dan PMK Nomor 210/PMK.010/2018. PP Nomor 80 Tahun 2019 mengatur tentang Perdagangan Melalui Sistem Elektronik. PP ini menjelaskan bahwa pelapak di Toko online atau e-commerce diwajibkan memiliki izin usaha. Selain itu, PMK Nomor 210/PMK.010/2018 mengatur tentang Perlakuan Perpajakan atas Transaksi Perdagangan melalui Sistem Elektronik. PMK ini mengatur mengenai tata cara dan prosedur pemungutan pajak. Hasil lebih jelas dapat dilihat pada grafik berikut ini.

Gambar 1

Pengetahuan Responden tentang Aturan Perpajakan

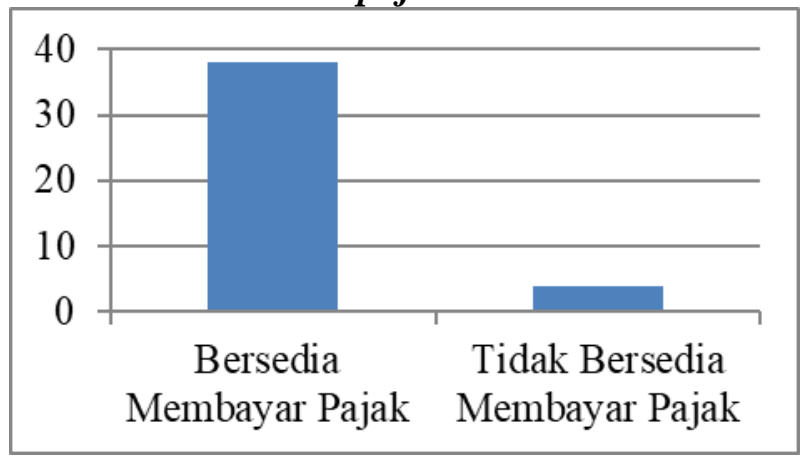

Sumber: data primer yang diolah (2019)

Berdasarkan Gambar 1 di atas, dapat diketahui bahwa hanya 12 pelaku usaha yang telah mengetahui adanya kebijakan baru untuk pelaku usaha yang melakukan aktivitas PMSE. Sisanya sebanyak 30 orang belum pernah mendengar atau membaca mengenai penerapan kebijakan tersebut. Hal ini menunjukkan bahwa masih banyak pelaku usaha yang tidak update informasi mengenai pajak dan kewajiban pajak yang harus mereka taati. Hal ini perlu direspon oleh pemerintah dengan melakukan literasi kebijakan perpajakan secara lebih luas. Ketidaktahuan pelaku usaha pada aturan perpajakan menjadi masalah bagi pemerintah. Potensi perpajakan dari transaksi e-commerce sangat besar. Apabila tidak dimanfaatkan dengan baik maka potensi tersebut menjadi hal yang sia-sia.

Selain memberikan pertanyaan mengenai pengetahuan terkait PP Nomor 80 Tahun 2019 dan PMK Nomor 210/PMK.010/2018. Responden juga diberi pertanyaan mengenai kesiapan sebagai wajib pajak dan patuh pada aturan perpajakan yang baru. Hasil menunjukkan bahwa sebagian besar pelaku usaha bersedia mendaftarkan diri sebagai PKP dan akan patuh pada aturan perpajakan. Hal tersebut dapat dilihat pada grafik di bawah ini.

\section{Gambar 2}

Niat Membayar Pajak Responden

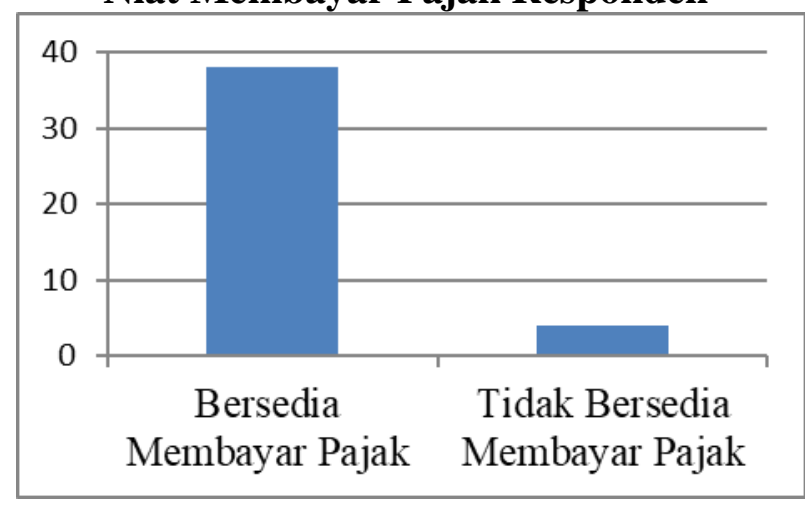

Sumber: data primer yang diolah (2019)

Berdasarkan gambar 2 di atas dapat disimpulkan bahwa pelaku usaha bersedia untuk patuh pada aturan perpajakan. Sebagai warganegara yang baik, wajib pajak harus taat pada peraturan perpajakan. Hal ini menunjukkan antusiasme pelaku usaha untuk turut serta membangun perekonomian negara dari sektor perpajakan. Pelaku usaha harus mendaftarkan diri sebagai PKP apabila telah memenuhi syarat yaitu memperoleh omzet lebih dari Rp 4,8 miliar.

Hasil pertanyaan terbuka mengenai pandangan pelaku usaha terhadap PP Nomor 80 Tahun 2019 dan PMK Nomor 


\section{DWI MARLINA WIJAYANTI \\ Pajak Digital: Potensi Dan Tantangan}

210/PMK.010/2018 menunjukkan bahwa kebijakan tersebut dianggap baik dan adil. Pelaku usaha berpendapat bahwa tidak ada salahnya membebankan pajak sejauh aturan yang mengikat jelas dan rasional. Beberapa responden bahkan berpendapat bahwa sudah selayaknya setiap pengusaha dibebankan pajak sesuai dengan manfaat yang mereka peroleh. Bagi responden yang belum mengetahui kebijakan perpajakan tersebut tetap setuju dan akan membayar pajak sesuai dengan kenetuan yang berlaku

\section{KESIMPULAN DAN SARAN \\ Kesimpulan}

Adanya peraturan pajak terkaitecommerce yang dibuat oleh pemerintah menunjukkan perhatian pemerintah untuk meningkatkan kepatuhan wajib pajak. Sebagai pelaku bisnis yang baik, makaperlumempersiapkan segala hal yang dibutuhkan untuk mematuhi dan melaksanakan kewajiban perpajakan dengan cara membayar pajak sesuai dengan aturan yang berlaku.PP Nomor 80 Tahun 2019 dan PMK Nomor 210/PMK.010/2018merupakan bukti dari usaha pemerintah untuk menangkap peluang dalam sektor perpajakan. Sektor OTT dapat meningkatkan perokonomian Indonesia karena banyaknya transaksi bisnis yang dilakukan. Pemerintah telah menetapkan kebijakan yang ditujukan untuk pelaku usaha yang melakukan PSME. Tetapi kebijakan yang dutujukan untuk perusahaan-perusahaan digital yang melakukan aktivitas bisnis di Indonesia masih dalam pembahasan.

Pemerintah memiliki kendala dalam menetapkan pajak untuk perusahaan digital besar seperti Google, Amazon, Facebook, dan lain sebagainya. Perusahaan tersebut tidak dapat dibebankan dengan $\mathrm{PPh}$ karena definisi dari BUT tidak meng-cover jenis perusahaan digital. Prinsip PPh adalah memiliki wujud secara fisik. Artinya, pengenaan pajak penghasilan lintas negara harus berpedoman pada keberadaan fisik perusahaan di
Indonesia. Perusahaan asing harus memiliki kantor perwakilan di Indonesia. Fakta di lapangan menunjukkan bahwa pada era industri 4.0 aktivitas bisnis yang lebih sederhana dan luas tanpa disertai dengan syarat yang kompleks. Bisnis digital tidak memiliki fungsi produksi seperti yang ada pada perusahaan manufaktur dan tidak memiliki gudang seperti perusahaan dagang. Perusahaan digital dapat melakukan aktivitas bisnis hanya dengan sebuah produk berupa aplikasi. Perubahan wujud bisnis ini harus direspon dengan tepat sesuai dengan karakteristik yang ada.

Respon pemerintah diwujudkan dengan mengeluarkan kebijakan terkait perpajakan. Kebijakan tersebut dapat berupa revisi pasal UU mengenai perpajakan, mengeluarkan Peraturan Pemerintah, dan melakukan pendefinisian ulang beberapa ketentuan perpajakan. Kebijakan yang telah disah kan adalah PP Nomor 80 Tahun 2019 dan PMK Nomor 210/PMK.010/2018. Kebijakan tersebut menekankan pada pelaku usaha yang melakukan PMSE atau melakukan aktivitas jual beli melalui platform e-commerce. Pelaku usaha yang melakukan aktivitas bisnisnya melalui e-commerce dan telah mencukupi persyaratan harus mendaftarkan diri sebagai PKP dan membayar pajak. Hal ini dapat mendukung perekonomian negara dari sketor pajak.

Berdasarkan survei yang dilakukan oleh peneliti pada pelaku usaha yang melakukan aktivitas bisnis pada platform e-commerce diketahui bahwa sebagian besar pelaku usaha belum mengetahui adanya aturan perpajakan terbaru. Dibutuhkan literasi untuk menyelesaikan masalah ini. Meskipun demikian, pelaku usaha bersedia untuk membayar pajak apabila mereka telah memenuhi persyaratan sebagai wajib pajak. Hal ini menunjukkan bahwa pelaku usaha mau turut serta berkontribusi pada perekonomian negara dengan menjadi wajib pajak yang taat pajak. Penelitian selanjutnya dapat lebih dalam membahas mengenai 


\section{JURNAL OPTIMUM, Volume 10, Nomor 1 Maret 2020}

faktor-faktor yang mempengaruhi individu untuk membayar pajak dan melakukan pengujian secara empiris.

\section{Saran}

Berdasarkan analisis, kebijakan yang dibutuhkan pada era digital adalah penerapan PPN pada perusahaan digital yang beroperasi di Indonesia. Ini merupakan salah satu cara yang paling rasional untuk menerapkan pajak pada perusahaan digital. Pemerintah juga telah merencanakan perusahaan seperti Google dan Amazon untuk menarik PPN dan menyetorkan PPN pada otoritas pajak. Perusahaan telah memenuhi syarat untuk menerapakan PPN sehingga tidak akan menyalahi aturan perundang-undangan yang telah ada. Selain itu, pemerintah perlu merevisi UU tentang pajak Pengahasilan, UU tentang PPN, dan UU mengenai Ketentuan Umum dan Tata Cara Perpajakan yang telah ada untuk disesuaikan dengan era industri 4.0. Hal ini ditujukan agar tidak adanya upaya penghindaran pajak yang dilakukan oleh perusahaan-perusahaan digital.

\section{DAFTAR PUSTAKA}

Ayers, Susan \& Steven E. Kaplan. 2005. Wrongdoing by Consultants: An Examination of Employees' ReportingIntentions. Journal of Business Ethics, 57, 121-137.

Barnes, Stuart J., \&Richard T. Vidgen. 2002. An Integrative Approach to The Assessment of E-commerce Quality. Journal of Electronic Commerce Research, 3 (3), 114- 127.

Boylan, Scott J. 2010. Prior Audits and Taxpayer Compliance:Experimental Evidence on the Effect of EarnedVersus Endowed Income. Journal of the American Taxation Association, 32 (2), 73-88.

Caballe, J., Panades, J. 1997.Tax Evasion and Economic Growth.Public Finance/Finances Publiques, 52 (3-4), 318-40.
Consulting, Anderson. 1999. E-commerce: what'sallthe fuss. Presentation, Section1,Vol.5.

Herawati, N., \& Bandi, B. 2017. Dua Puluh Tahun Riset Perpajakan dalam Akuntansi: Suatu Studi Bibliografi. Jurnal Akuntansi dan Keuangan, 19(2), 102-121.

Herawati, N., \& Bandi, B. 2019. Telaah Riset Perpajakan di Indonesia: Sebuah Studi Bibliografi. Jurnal Dinamika Akuntansi dan Bisnis, 6 (1), 103-120.

Hongler, Peter \& Pasquale Pistone. 2015. Nexus to Tax Business Income in the Era of the Digital Economy. Working Paper. IBFD. Blueprints for a New PE nexus.

https://www.gatra.com/detail/news/457263/te knologi/kominfo-83-pengguna-internetadalah-pengguna-whatsappdiakses pada 26 Desember 2019 oleh Annisa Setya Hutami

https://www.online-pajak.com/pajak-ecommerce-online diakses pada 27 Desember 2019 oleh Onlinepajak

https://www.online-pajak.com/pajak-di-eradigital diakses pada 30 Desember 2019 oleh Kezia Rafinska

https://cita.or.id/news/citax/menilik-potensipajak-sektor-jasa-digital-dengan-skemappn/ diakses pada 30 Desember 2019 oleh KONTAN.CO.ID

https://cita.or.id/news/citax/punya-potensibesar-ekonomi-digital-butuh-aturanperpajakan/ diakses pada 30 Desember 2019 oleh KUMPARAN.COM

Isyrin, Mei. 2019. Digitalisasi Pajak di Indonesia dan Tantangan Penerapannya dalam Masyarakat. JOUR.

Klopping, Inge M. \& Earl. 2004. Extending the Technology Acceptance Model and the Task-Technology Fit Model to Consumer E-commerce.Information Technology, Learning, and Performance Journal, 22, (1), 35-47 


\section{DWI MARLINA WIJAYANTI}

\section{Pajak Digital: Potensi Dan Tantangan}

Nurdianto, Ardi. 2019. Tantangan Perpajakan dalam Revolusi Industri 4.0. MUC Consulting

Posner, Eric A. 2000. Law and Social Norms: The Case of Tax Compliance. Virginia Law Review, 68 (8), 1781-1819.

PP Nomor 80 Tahun 2019 tentang Perdagangan Melalui Sistem Elektronik

PMK Nomor 210/PMK.010/2018 tentang Perlakuan Perpajakan atas Transaksi Perdagangan Melalui Sistem Elektronik (E-commerce)
Richard, M. 2018. Peluang dan Tantangan Meningkatkan Penerimaan Pajak. Bisnis.com Rosdiana, Haula, Inayati, Murwendah, Lucas Filberto Sardjono, Indriani, \& Vishnu Juwono. 2017. Kebijakan Pajak atas Idle Land: Peluang dan Tantangan. ORTAX.

Shevlin, T. 1999. Research in Taxation. Accounting Horizons, 13(4), 427-441.

Turnovsky, S.J. 1997. Fiscal Policy in a Growing Economy with Public Capital. Macroeconomic Dynamics, 1, 615- 